\title{
Rosacea disease and Demodex spp. relationship; Retrospective study
}

\section{Rosacea hastalığ|l ve Demodex spp illişkisi,; Retrospektif çalışma}

\author{
Necati Ozpinar ${ }^{1}$, Mustafa Tosun²
}

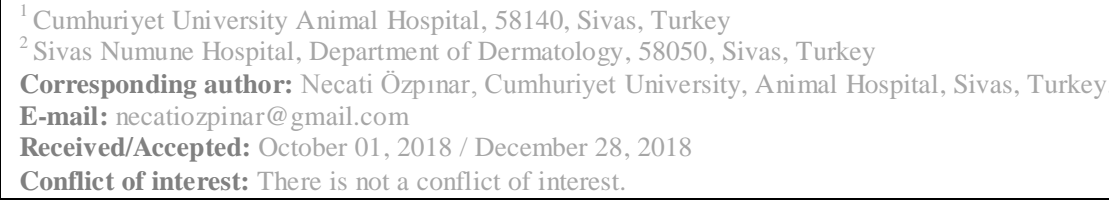

\section{SUMMARY}

Objective: Purpose of this study is to determine the prevalence of Demodex spp.among the patients diagnosed with Rosacea.

Method: In our study, the patient group who visited Sivas Numune Hospital Dermatology Outpatient Clinic between January 01, 2018 and September 25, 2018, and was diagnosed with Rosacea was observed with respect to Demodexspp.Samples were taken from 338 patients with the procedure of Standardized Skin Surface Biopsy (SSSB).

Results: The presence of Demodex spp. was found to be positive in 166 (49.1 percent) of 338 rosacea patients. When the patients are evaluated based on gender, 17 ( 28.9 percent) of 59 male patients and 136 (48.7 percent) of 279 female patients were detected to have Demodex spp.and this difference was statistically significant (Table 1). Positivity of Demodex spp. based on gender was deemed statistically significant $(\mathrm{p}<0.05)$. As a result of the analysis by gender groups, Demodexspp. was identified in 13 (23.6 percent) of 55 rosacea patients under the age of 20 years, 75 (48.7 percent) of 154 patients between the age of 20 and 40 years and 78 (60.4 percent) of 129 patients over the age of 40 yearsand the difference between groups was statistically significant $(\mathrm{p}<0.05$, Table 2$)$. Positivity of Demodex spp.based on age groups was found statistically significant $(\mathrm{p}<0.05)$.

Conclusions: It was surmised that Demodex spp. plays an important role in aetiopathogenesis of rosacea disease, this parasite should be considered during the treatment planning of the disease and rosacea patients should be investigated in terms of Demodex spp.

Keywords: Rosacea, Demodex spp, Retrospective study

\section{ÖZET}

Amaç: Bu çalışmanın amacırosacea tanısı konmuş hastalardaDemodex spp. yaygınlığını belirlemektir.

Yöntem: Çalışmamızda Sivas Numune Hastanesi Dermatoloji polikliniğine 01.01.2018 ve 25.09.2018 tarihleri arasında gelen ve rosacea tanısı konmuş hasta grubuDemodexspp yaygınlığı açısından incelendi. Çalışmada 338 hastadan standart deri yüzey biyopsisi (SDYB) yöntemi ile örnekler alındı.

Bulgular: Üçyüz otuz sekiz rosacea hastasının $166(\% 49,1)$ 'sındaDemodex spp. pozitif bulundu. Bu durum cinsiyete göre değerlendirildiğinde 59 erkek hastada Demodex spp. pozitifliği $17(\% 28,8)$ iken 279 kadın hastanın136 $(\% 48,7)$ idi ve bu fark istatistiksel olarak anlamlıydı (Tablo 1). Cinsiyete göre Demodex spp. pozitifliği istatistiksel olarak önemli bulundu $(\mathrm{p}<0,05)$. Yaş gruplarına göre yapılan inceleme sonucunda 20 yaşın altındaki rosacea hastalarında 55 hastanın 13 (\%23,6)'ünde, 20-40 yaşları arası hastaların $75(\% 48,7)$ 'inde, 40 yaş üzeri 129 hastanın ise $78(\% 60,4)$ 'inde Demodexspp. saptandı ve gruplar arası fark istatistiksek olarak anlamlıydı $(\mathrm{p}<0,05$, Tablo 2). Yaş gruplarına göre Demodex spp. pozitifliği istatistiksel olarak önemli bulundu $(\mathrm{p}<0,05)$.

Sonuç: Rosacea hastalığının etiyopatogenezinde Demodex spp. nin önemli rolü olduğu, bu hastalığın tedavisi planlanırken bu parazitin göz önünde bulundurularak, rosacea hastalarının Demodex spp. açısından araştırılması gerektiği kanısına varılmıştır.

Anahtar sözcükler: Rosacea, Demodex spp, Retrospektif çalışma 


\section{INTRODUCTION}

Rosacea is a prevalent dermatologic disease that is seen in approximately 3 percent of society and affects center region of face ${ }^{1}$. It is characterized by central fascia erythema, telangiectasia, papule and pustular lesions which can be observed in face temporarily or permanently. The most frequent symptoms of the disease are burning, redness, swelling, dryness and eye lesions. Rosacea is divided into four types: erythematotelangiectatic, papulopustular, phymatous and ocular rosacea ${ }^{2}$. Rosacea is usually seen between the age of 30 and 50 years and more prevalent in females than in males. The disease is observed more commonly in the individuals with one or two skin types according to Fitzpatrick classification scale ${ }^{3}$.

Although the cause of rosacea is not clarified exactly in literature, the frequent causes can be listed as immune dysregulation, vascular diseases, external causes, degeneration of connective tissue elements, dysfunction of pilosebaceous unit, chemical factors and infections ${ }^{1}$. The foremost factor related to rosacea among infections is Demodex spp.parasite. In the studies conducted with rosacea patients, density of Demodex spp.was found to be significantly higher than that in the control group which does not have rosacea disease ${ }^{4}$.

There are more than 100 species of Demodex parasites $^{2}$. Two species were identified to live in human skin: Demodex folliculorum and Demodex brevis. Bodies of both types are worm-like with a length of $0.1-0.4 \mathrm{~mm}$. They generally live in hair follicles and sebaceous glands in face region of humans in which they are commonly seen 5 .

This study is a retrospective study which determines the prevalence of Demodexspp. in rosacea patients who consulted Sivas Numune
Hospital Dermatology Outpatient Clinic between January and September, 2018.

\section{MATERIAL AND METHODS}

In our study, the patient group who visited Sivas Numune Hospital Dermatology Outpatient Clinic between January 01, 2018 and September 25, 2018, and was diagnosed with rosacea was observed with respect to Demodexspp. Samples were taken from 338 patients with the procedure of Standardized Skin Surface Biopsy (SSSB). For this purpose, a circle with a diameter of almost 1.12 was drawn on the surface of lame with a glass dip pen. A drop of cyanoacrylate (super glue) was applied to inner area of the circle on the other side of lame. Later, the sticky side of lame was pressed onto the skin of patient and kept there for about one minute. After a while, the lame was lifted up slowly. A drop of immersion oil was applied to the sample and the sample was covered with lame. Preparations analyzed with a magnification of 10x and 40x were evaluated with regard to Demodex spp. ${ }^{6}$.

\section{Statistical Analysis}

The data obtained in our study was loaded to SPSS (Ver: 22.0). Parametric test assumptions could not be fulfilled in the evaluation of data, so chi square test was used and 0.05 was applied as level of significance.

\section{RESULTS}

A total of 338 rosacea patients were included in the study by Sivas Numune Hospital Dermatology Outpatient Clinic. Of the patients, 59 (17.4 percent) and 279 (82.6 percent) were males and females, respectively. Of 338 patients, 55 (16.3 percent) were under the age of 20 years, 154 (45.5 percent) were between the age of 20 and 40 years, and 129 (38.2 percent) were over the age of 40 years (Table 1-2). 
Tablo 1: Demodex spp. gender distribution

\begin{tabular}{|l|l|l|l|l|}
\hline \multirow{2}{*}{ Groups } & \multicolumn{2}{|l|}{ Pozitive } & \multicolumn{2}{l|}{ Negative } \\
\cline { 2 - 5 } & $\mathrm{N}$ & $\%$ & $\mathrm{~N}$ & $\%$ \\
\hline Male & 17 & 28,8 & 42 & 71,2 \\
\hline Female & 136 & 48,7 & 143 & 51,3 \\
\hline \multicolumn{4}{|l}{ Khi kare: $\mathrm{p}<0,05, \mathrm{~N}:$ Number of patients } \\
\hline
\end{tabular}

Tablo 2: Demodex spp. distribution by age

\begin{tabular}{|l|l|l|l|l|}
\hline \multirow{2}{*}{ Groups } & \multicolumn{2}{|l|}{ Pozitive } & \multicolumn{2}{l|}{ Negative } \\
\cline { 2 - 5 } & $\mathrm{N}$ & $\%$ & $\mathrm{~N}$ & $\%$ \\
\hline$<20$ & 13 & 23,6 & 42 & 76,4 \\
\hline $20-40$ & 75 & 48,7 & 79 & 51,3 \\
\hline$>40$ & 78 & 60,4 & 51 & 39,6 \\
\hline \multicolumn{4}{|l|}{ Khi kare: $\mathrm{p}<0,05$, N: Number of patients } \\
\hline
\end{tabular}

In consequence of the research, presence ofDemodex spp. was found to be positive in 166 (49.1 percent) of 338 rosacea patients. When the patients are evaluated based on gender, 17 (28.9 percent) of 59 male patients and 136 (48.7 percent) of 279 female patients were detected to have Demodex spp. (Table 1). Positivity of Demodex spp. based on gender was deemed statistically significant $(\mathrm{p}<0.05)$. As a result of the analysis by gender groups, Demodexspp. was identified in 13 (23.6 percent) of 55 rosacea patients under the age of 20 years, 75 (48.7 percent) of 154 patients between the age of 20 and 40 years and 78 (60.4 percent) of 129 patients over the age of 40 years (Table 2). Positivity of Demodex spp.based on age groups was found statistically significant $(\mathrm{p}<0.05)$.

\section{DISCUSSION}

Distribution of Demodex species is cosmopolitan. Even though the pathogenicity of this parasite is still contradictive, there are several researches that indicate the role of the parasite in aetiopathology of numerous dermatologic diseases ${ }^{7-9}$. It was identified that the prevalence of parasites increases in direct proportion to age. The first Demodex folliculorumfact in human in our country was detected after the analysis of the preparation taken form perineal region through cellophane band method ${ }^{10,11}$. Presence ofDemodex spp. in human tissue as an imperious and permanent parasite in human skin, and its prevalence which rises in direct proportion to age complicate determination of the pathogenicity of this factor. However, the density of Demodex folliculorum/ $\mathrm{cm}^{2}$ is substantial in cases of rosacea, perioral dermatitis, seborrheic dermatitis and micropapular itchy dermatitis, and prognosis of these diseases improves gradually after the specific treatments against the mite, therefore it makes think that the mite has a role in pathogenesis of such diseases ${ }^{11}$.

Age is a significant factor in the prevalence of Demodex spp. Thus, it is more commonly found in older individuals. The prevalence rate which is 20 percent among the group under the age of 20 years goes up as the age rises. In another study conducted with 47 Chronic Renal Failure (CRF) patients and control group in Sivas, skin samples from cheek and eyelashes were analyzed. Of 47 CRF patients, 6 (12.76 percent) and 12 (23.53 percent) were detected to have Demodex folliculorumin their eyelash follicles and in their faces, respectively. In control group, Demodex folliculorumwas found in eyelash follicles of 2 (5.26 percent) individuals and in face of 7 (18.42 percent) individuals ${ }^{12}$. Additionally, many studies assert the important role of Demodex spp. in pathogenesis of rosacea disease. In a study, Demodex spp. was screened among the patients prediagnosed with rosacea. Demodex folliculorum 
was identified in 5 (17.85 percent) male and 10 (35.71 percent) female cases whereas Demodex breviswas seen in 2 (7.14 percent) female cases. Thus, 17 (60.7 percent) of 28 cases were found to have Demodex spp. It was concluded in this study that primary investigation of the suspicious rosacea lesions especially in face region of humans with regard to Demodex spp. will be useful for early diagnosis and treatment ${ }^{13}$. As part of another study, 197 patients (117 rosacea patients, 29 acne vulgaris patients and 51 patients with other allergic complaints) were examined with the procedure of SSSB. The presence of mite was found to be positive in 97 (49.23 percent) of 197 patients. Even though no statistically significant difference was determined, positivity in rosacea and negativity among the patients under the age of 20 years were detected to be significantly high. Eventually, it was surmised that it is essential for the patients with various allergic skin diseases, particularly for rosacea patients over the age of 20 years to be investigated in terms of infestation of Demodex spp. ${ }^{5}$. A study which included the cases clinically and histopathologically diagnosed with demodectic rosacea was performed to search the effects of permethrin $5 \%$ cream and metronidazole $0.75 \%$ gel on severity score of rosacea and on one of the lesions, Demodexeradication. The researchers concluded in this study that permethrin $5 \%$ cream may have anti-inflammatory effects as well as acaricidal effect on Demodexspp. among rosacea patients, and may be a new alternative drug in this treatment. For above reasons, they surmised that the role of Demodexesspp. is supported in pathogenesis ${ }^{14}$.

All in all, Demodex spp. was detected to be positive in 166 (49.1 percent) of 338 rosacea patients in our study. This rate made us think that Demodex spp. plays a substantial role in aetiopathogenesis of rosacea disease. It was found out that this parasite should be considered during the planning of rosacea treatment and rosacea patients should be investigated with respect to Demodex spp.as well.

\section{REFERENCES}

1. Jarmuda S, O'Reilly $\mathrm{N}$, Żaba R, Jakubowicz O, Szkaradkiewicz A, Kavanagh K. Potential role of Demodex mites and bacteria in the induction of rosacea. J Med Microbiol. 2012;61:15041510.

2. Crawford GH, Pelle MT, James WD. Rosacea: I. Etiology, pathogenesis, and subtype classification. $J$ Am Acad Dermatol. 2004;51:327-341.

3. Del JR. Update on rosacea pathogenesis and correlation with medical therapeutic agents. Cutis. 2006;78:97-100.

4. Erbagci Z, Ozgoztasi O. The significance of Demodex folliculorum density in rosacea. Int J Dermatol. 1998;37:421425 .

5. Aycan OM, Otlu GH, Karaman U, Daldal N, Atambay M. Frequency of Demodicosis in Various Patient and Age Groups. Turkish J Parasitol. 2007;31:115-118.

6. Balcioglu I, Yolasigmaz A. Diagnosis of arthropods of medical importance. Korkmaz M, Ok UZ, editurs. Laboratory in Parasitology. Izmir: Meta Issue2011:132.

7. Forton F. Elucidating the role of Demodex folliculorum in the pathogenesis of rosacea: exciting first steps. Br J Dermatol. 2018;179:252-253.

8. Unal E, Akcinar UG, Arduc A. Hidradenitis suppurativa, metabolic syndrome, and Demodex spp. infestation. Turkish J Parasitol. 2018;42:171-174.

9. Bilal N, Kirisci O, Ozkaya E. Demodex Species Infestation in Patients with Ear Itching and Its Relationship to Itch Severity. Turkish J Parasitol. 2017;41:87.

10. Saygi G. Parasitic diseases. Sivas: Es Form Ofset. 2009:269-271.

11. Yolasigmaz A, Budak S. Demodicosis. Özcel MA, Özbel Y, Ak M, editors. Ozcel's Medical Parasitic Diseases. İmir: Meta Basim 2007.

12. Ozcelik S, Sumer Z, Degerli S, et al. The incidence of Demodex folliculorum in patients with chronic kidney deficiency Turkish J Parasitol. 2007;31:66-68.

13. Yucel A, Yilmaz M. Investigation of the prevalance of Demodex folliculorum and Demodex brevis in rosacea patients. Turkish J Parasitol. 2013;37:195.

14. Aydogan $\mathrm{K}$, Baskan EB, Tunali Ş. A comparison of efficacy of $.75 \%$ metronidazole geland 5\% permethrin cream in the treatment of rosacea. Turkiye Klinikleri J Dermatol. 2001;11:94-101. 